
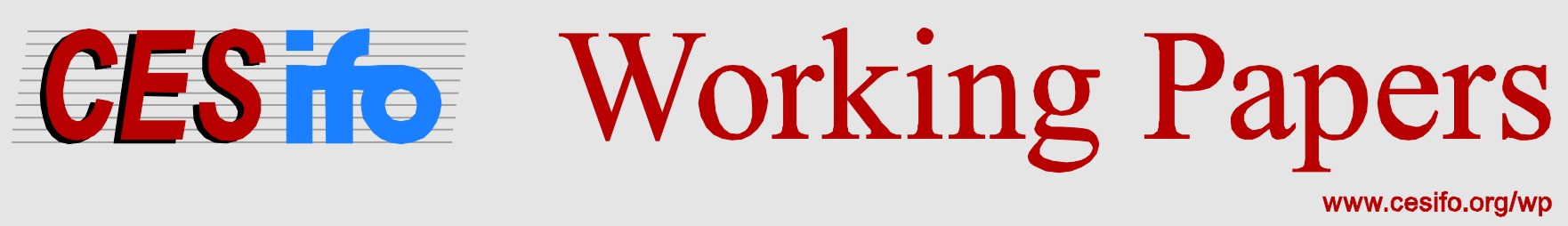

\title{
Adults' Financial Literacy and Households' Financial Assets: The Role of Banks Information Policies
}

\author{
Margherita Fort \\ Francesco Manaresi \\ Serena Trucchi
}

\author{
CESIFO WORKING PAPER NO. 5047 \\ CATEGORY 12: EMPIRICAL AND THEORETICAL METHODS \\ OCTOBER 2014
}

An electronic version of the paper may be downloaded

- from the SSRN website:

- from the RePEc website:

- from the CESifo website:

wWw.SSRN.com

www.RePEc.org

www.CESifo-group.org/wp 


\title{
Adults' Financial Literacy and Households' Financial Assets: The Role of Banks Information Policies
}

\begin{abstract}
JEL-Code: D140, G110. variables.

\author{
Margherita Fort* \\ Department of Economics \\ University of Bologna \\ Piazza Scaravilli 2 \\ Italy - 40126 Bologna \\ margherita.fort@unibo.it
}

We investigate the role of banks information policies in fostering the accumulation of financial knowledge. In Italy, banks belonging to the PattiChiari Consortium implement policies aimed at increasing transparency and procedural simplification, without offering services at lower cost with respect to other banks. We exploit this feature of the Italian banking system and show that these policies promote financial literacy. The increase in financial knowledge attributable to banks information policies significantly affects household financial assets. We use these policies as instruments to estimate the effect of financial literacy on financial assets, showing that it is significantly underestimated by OLS correlation.

Keywords: banks information policies, financial assets, financial literacy, instrumental

Francesco Manaresi

Structural Economic Analysis Department

Bank of Italy

francesco.manaresi@bancaditalia.it
Serena Trucchi

Department of Economics

University of Bologna / Italy

serena.trucchi@unibo.it 


\section{Introduction}

Both in Europe and in the U.S. there is evidence of low levels of financial literacy and a limited knowledge of basic economic concepts, like inflation or interest compounding (Lusardi and Mitchell, 2014, 2011c; Jappelli, 2010). Lack of financial literacy and the mis-perception of crucial economic factors may lead individuals to make suboptimal investment choices and, thus, reduce individual wealth. For this reason, a growing number of countries have implemented national strategies to foster financial literacy in the population (see OECD (2013a) for a review). These strategies usually emphasize the role of formal financial education in schools or at the workplace ${ }^{1}$

In this paper, we study a different channel through which financial literacy can be improved, which received, so far, very little attention in the literature: banks information policies. Indeed, rules and actions engaged by banks aimed at increasing transparency and simplifying the relationship with the client may reduce the cost of acquiring financial knowledge without imposing any additional burden to the customer in terms of time, effort or resources. To assess the effectiveness of these policies, we exploit a peculiar feature of the Italian banking system: the existence of a Consortium of banks (PattiChiari) which has the direct aim of implementing information policies and foster financial literacy. We argue that the cost of acquiring financial knowledge is lower for clients of banks that joined the Consortium and we investigate how this reflects into changes in the level of financial literacy. Evidence that there is no self-selection of clients into PattiChiari banks allows us to overcome one of the main issues in the evaluation of voluntary financial education programs (OECD, 2013a) and to interpret our findings as causal.

Our results point to important consequences of banks information policies in Italy: being client of a PattiChiari bank increases household financial literacy by $10 \%$ (about one fourth of a standard deviation of our measure of financial literacy). This result complements findings by Mastrobuoni (2011), who shows a significant impact of the availability of information on workers' knowledge of their social security benefits in the U.S.. Our paper adds to the literature aimed at evaluating the effectiveness of alternative formal educational interventions on financial literacy (Lusardi and

\footnotetext{
${ }^{1}$ There is an open debate about the effectiveness of alternative financial education programs on financial literacy and financial behaviour (Willis||2011|| Lusardi and Mitchell||2014). Robust and reliable empirical evidence on the evaluation of their effects is still limited and this motivates some skepticism on the role played by financial education in improving financial knowledge and household financial welfare (Willis $\mid 2011$ ).
} 
Mitchell, 2014) by showing that transparency and procedural simplification policies of financial institutions may represent an alternative way to improve financial knowledge among adults. Even when formal financial education programs affect financial literacy, biases, heuristics and non rational influences may weaken their effectiveness on individual financial behaviour (Hastings et al., 2013). In this respect, OECD (2013b) offers some guidance on how program effectiveness can be improved. The banks information policies we consider in the paper are in line with these suggestions.

A second contribution of this paper is to provide a new instrumental variable strategy to assess the effect of financial literacy on financial assets: we exploit banks information policies for identification. The association between financial literacy and several economic decisions (risk diversification, debt exposure and retirement planning) has been widely documented, yet the evidence about the strength of the causal relationship between these factors is recent and still limited. Most studies report that simple regression correlations provide a lower bound of the true effect, but estimates of this bias vary a lot from one study to the other. Unobserved heterogeneity, simultaneity (Jappelli and Padula, 2013b) and measurement error (van Rooij et al., 2011b) typically plague empirical results and are difficult to address in this setting. In line with previous analyses, we show that the causal effect of financial literacy on financial assets is underestimated by OLS correlation. In particular, we find that a one standard deviation increase in financial literacy leads to an increase of household assets of around 8 thousands euros. We offer some insights about the channels through which this effect takes place, showing that financial literacy promotes the propensity of households to participate to stock market (van Rooij et al., 2011b c, Christelis et al. 2010). Conversely, we do not find evidence of a higher attitude to plan for retirement (Lusardi and Mitchell, 2011a).

Our strategy is robust to a number of falsification checks. First-stage statistics show that the instrumental variable we use is not weak (Staiger and Stock, 1997) and the availability of multiple instruments for financial literacy allows us to run an over-identification test that supports the causal interpretation of our findings.

The paper is organized as follows. We start by briefly reviewing the related literature, mainly focusing on empirical contributions (Section 2). We then describe the main features of the PattiChiari Consortium, namely services provided by banks in the Consortium to their clients, and how and why banks join it (Section 3. We also highlight the channels through which these services may foster financial literacy. We present the data used to perform our analysis in Section 4. Section 5 illustrates our empirical approach and discusses the hypothesis at the core of the 
identification strategy. We present our main findings in Section 6 and we discuss the results of an over-identification test and several falsification checks, including sensitivity to sample selection and modelling choices, in Section 7. Conclusions follow.

\section{Related Literature}

Our paper relates to the literature that analyzes tools aimed at fostering financial literacy. Lusardi and Mitchell (2014) and Hastings et al. (2013) represent the most recent reviews on these topics. They cover a) the measurement of financial literacy; b) the relationship between financial education, financial literacy and financial outcomes; c) the role of interventions. Both reviews point out the shortage of rigorous evaluations of the impact of financial education programs, making it difficult to draw inference on their effectiveness. One of the main issues that motivates the lack of empirical evidence is the difficulty of proving causal links (OECD, 2013a): selective participation into programs and non-random attrition, on the one hand, and measurement issues related to financial literacy and financial behaviour, on the other hand, make this task empirically challenging. Thus, the debate about the effectiveness of different interventions on financial literacy and economic behaviour is still open $2^{2}$

The literature on the links between financial literacy and financial decisions in economics and behavioural finance (see the recent review by Garcia 2013) suggests that the difficulty of processing complex information might be relevant for financial decision-making, and promote "the widest dissemination possible of some suitable financial rules" (Garcia, 2013). OECD (2013a) offers some guidance on how the effectiveness of financial education programs can be improved, in line with what suggested by papers in the area of behavioural finance (Altman, 2012). According to these remarks, education programs should: i) offer material in formats and locations that are easy to access; ii) help consumers to simplify financial decisions, for instance breaking them in intermediate steps or providing rules-of-thumb or problem-solving strategies; iii) increase saliency by providing participants with regular reminders or tools to track and visualise individual progress. The banks

\footnotetext{
${ }^{2}$ Alternative actions are (possibly mandatory) financial education programs (Lusardi and Mitchell, 2014) or policies targeted to consumers' financial outcomes, ranging from imposing stricter regulation to financial advisors, to publicly providing financial information, to "nudging" correct financial behavior of consumers through economic incentives (Hastings et al. 2013).
} 
information policies we consider in the paper are in line with these suggestions.

The case study considered in this paper adds empirical evidence on the direct effects of providing basic and simple information on financial knowledge, and on the indirect effects - mediated by improved financial knowledge - on households' financial assets. Even if we cannot directly perform a horse-race between interventions, we show the effectiveness of a different tool to foster adult financial literacy (and financial assets) and may complement educational interventions. Our results are in line with findings by Mastrobuoni (2011), who shows that the availability of information on social security benefits in the U.S. has significant impact on workers' knowledge. While in the case-study evaluated by Mastrobuoni (2011) the improved knowledge does not change retirement behaviour - i.e. the intention-to-treat effect is not significant -, we find that banks information policies significantly affect both financial literacy and the amount of financial assets. As we stress in Section 5 and 7 , the intention-to-treat effect on financial wealth is explained by improved financial literacy.

Our paper also relates to the literature that investigates the causal effect of financial literacy on financial outcomes. Jappelli and Padula (2013b) and Lusardi et al. (2011) provide a theoretical framework to analyse the investment in financial literacy and its impact on wealth in the context of inter-temporal utility maximization. These models highlight that financial literacy and wealth are simultaneously determined and that the incentives to invest in financial literacy may depend on the level of wealth, raising the issue of the potential endogeneity of financial literacy in the wealth equation 3 Endogeneity of financial literacy in the wealth equation may also arise because of omitted variable bias or substantial measurement error in financial literacy (Lusardi and Mitchell, 2009 van Rooij et al., 2011b), as we discuss in more detail in Section 5.

Some recent papers have addressed this potential endogeneity problem pursuing instrumental variable strategies for identification. However, empirical studies assessing a causal link between financial literacy and financial outcomes are still rare (Hastings et al., 2013). Finding an exogenous source of variability in this setting is difficult and most of the identification strategies adopted in observational studies so far are not free from criticism 4 These papers can be grouped into three

\footnotetext{
${ }^{3}$ However Lusardi and Mitchell (2007) show that the instrumental variable estimate of the impact of wealth on financial literacy is not statistically significant. They interpret this finding to support the absence of reverse causality in their data.

${ }^{4}$ We refer to Lusardi and Mitchell 2014) for a detailed discussion of the instruments proposed in the literature
} 
broad categories. A first group of papers exploit as instruments pre-labour market endowment of financial knowledge (Jappelli and Padula, 2013b; Disney and Gathergood, 2011, van Rooij et al. 2011c). van Rooij et al. (2011c) are skeptical about the validity of the exclusion restriction for the instrumental variable they use and discuss the issue at length in the paper, adding a rich set of controls to their baseline specification. Other studies hinge on the idea that the respondent's financial literacy is influenced by financial knowledge of peers or reference groups (Bucher-Koenen and Lusardi, 2011; Klapper and Panos, 2011; Klapper et al., 2013, Fornero and Monticone, 2011, Jappelli and Padula, 2013a; van Rooij et al. 2011c a). The assumption that lies behind this identification strategy is that the respondent cannot influence the peers' experience significantly, i.e. there is no "reflection problem" (Manski, 1993). A more convincing instrumental variable strategy is proposed by Lusardi and Mitchell (2011b). They take advantage of the fact that several U.S. states mandated high school financial education in the past and exploit the exogenous variation in financial literacy induced by the exposure to the mandate to identify the effect of financial literacy on planning for retirement. Our paper does not belong to any of these categories and proposes a new strategy to identify the causal effect of financial literacy on household wealth that exploits, for the first time, the role of banks information policies in fostering household financial knowledge. Moving from the assumption that acquiring financial knowledge is a costly process (Jappelli and Padula, 2013b), we argue that banks information policies undertaken by a specific subset of Italian banks may decrease the cost of acquiring financial literacy without imposing additional burden to the client in terms of time, effort or resources (see Section 3 and 5 for more details). We exploit this exogenous source of variation in the cost of acquiring financial knowledge to investigate the effect of financial literacy on financial assets.

As pointed out Lusardi and Mitchell (2014), most studies find that the OLS estimate of the impact of financial literacy is biased downward but the estimates differ a lot across papers and the magnitude of the bias varies largely in the literature ${ }^{5}$ Our findings confirm the downward bias of OLS estimate, showing that causal effect is four times larger.

\footnotetext{
(an insightful synthesis is provided in Table 4, p.28).

${ }^{5}$ The instrumental variable estimates range from three times larger the corresponding OLS estimates van Rooij

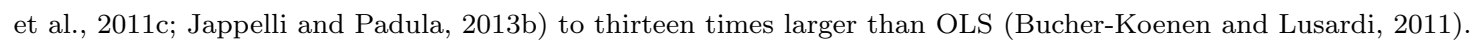




\section{The PattiChiari Consortium}

This Section describes the main features of the PattiChiari Consortium, how and why banks join it, and the range of services provided by banks in the Consortium. It highlights the channels through which these services may foster financial literacy.

The PattiChiari Consortium has been created in 2003 by the Italian Banking Association (Associazione Bancaria Italiana: ABI, henceforth). In 2010, 98 banks joined it, corresponding to around $64 \%$ of all bank branches in the Italian territory. The distribution over the Italian territory is characterized by some regions (such as Trentino-Alto Adige and Calabria) where there are few PattiChiari branches and others (e.g., Piedmont and Sardinia) where over $80 \%$ of branches belong to a PattiChiari bank. The share of PattiChiari branches is however homogeneous across broader geographical areas: about $63 \%$ in northern Italy, $67 \%$ in central Italy, $64 \%$ in southern Italy. In our empirical specification, we take into account any geographic differences by including either province or municipal fixed-effects.

The aim of the PattiChiari Consortium is twofold: foster banking transparency and enhance financial education of Italian households ${ }^{6}$ Regarding the former, a bank that joins the Consortium must introduce a set of "Quality Commitments" (so called "Impegni per la qualità"). In the period we analyse (year 2010), these commitments refer to information about mortgage and debt and to comparability of current accounts. In what follows, we present these two commitments in detail.

Information about mortgage and debt. Every month PattiChiari banks send by mail a mortgage statement to their clients. This statement includes information on total and residual amount of debt to be paid and on the residual number of installments, and reminders information about penalties. In addition, a 24-pages booklet was available in each PattiChiari branch. The booklet covered several topics related to mortgages and provided definitions of more general economic concepts: 7 Each section included examples about the calculation of interest rates and installments and provided

\footnotetext{
${ }^{6}$ The Consortium has implemented a set of formal financial literacy programs in Italian schools and, starting in 2012 , in workplaces and cultural and charitable associations.

${ }^{7}$ More specifically it referred to mortgage portability, substitution or renegotiation; mortgage resolution and redemption. It gives a definition for amortization plan, mortgage resolution, Euribor (Euro Interbank Offered Rate), IRS (Interest Rate Swap), Eurirs (Euro Interest Rate Swap), fixed-rate, adjustable-rate and mixed-rate mortgages, TAEG (synthetic indicator of the cost of the mortgage), portability, installment, spread, renegotiation, and subrogation.
} 
several remarks $\mathrm{B}^{8}$ An example of its content is the following remark (our translation from Italian): "WARNING: With a lower mortgage payment the duration of the mortgage increases. Therefore, the total amount of interest paid on the mortgage will be higher, because the number of installments increases".

Comparability of current accounts. Costs, interest rates and general contract conditions of bank accounts vary both across and within banks. For instance, one bank may offer up to 12 different bank accounts tailored to a specific type of customer (eg. household, retired, younger than 18, etc.). The PattiChiari Consortium provides a search engine that allows the direct comparison of specific characteristics of bank accounts across different banks, as well as the information on the location of bank's branches. Thanks to the provision of detailed information on interest rates, we expect households to become more aware about how current accounts work and more accustomed to concepts like interest rate compounding.

The "Quality Commitments" described above are in line with the OECD suggestions to improve the effectiveness of education programs (OECD, 2013b). Indeed, they provide informative material on a regular basis (costumers receive the mortgage statement every month) in format and location that are easy to access (mail, bank branch and websites). These interventions are designed to simplify costumers decision problems, providing definitions and synthesis of basic and simple information about relevant economic concepts, such as amortization plans and interest rates compounding, sometimes through examples. These concepts are closely related to the standard questions used to measure financial literacy in the literature and in our paper (see Appendix A for the exact wording of the questions used to measure financial literacy). At the same time, the "Quality Commitments" are not directly related to the provision of formal financial advice and do not typically take this form. However, they can indirectly impact the probability of consulting an advisor and delegating the portfolio choice management if, as shown by Calcagno and Monticone (2014), it depends on financial literacy.

\footnotetext{
${ }^{8} \mathrm{~A}$ copy of the booklet, available in Italian only, can be downloaded from the URL https://web.archive.org/web/20111030200724/http://www.pattichiari.it/dotAsset/12557.pdf
} 
Why Banks Join the PattiChiari Consortium?. 9 Application to the PattiChiari Consortium is decided at the bank level, and it involves all the branches on the Italian territory. Any bank can apply to be a member of the Consortium, provided that it undertakes the "Quality Commitments", and applications are evaluated by Patti Chiari board of directors. If a member bank does not meet the requirements, it can be fined and excluded from the Consortium 10 Concerning the advantages of entering in the PattiChiari Consortium, banks improve the quality of supplied services and customer satisfaction, and expect clients to become more able to understand economic concepts and offers. They may also benefit from informative advertising provided by the Consortium. Informative advertising can benefit both the firm that makes the investment (in our application a bank belonging to the PattiChiari consortium) and its competitors, through an increase in savings, stock market participation and the demand for financial services in general (Hastings et al. 2013). Free-riding problems may induce underprovision of informative advertising. In our case, however, the fact that over $60 \%$ of all bank branches belong to the Consortium should mitigate the incentive to free-ride. Considering the cost of joining the Consortium, menu costs make the commitment regarding the comparability between current accounts the most demanding task for member banks.

\section{Data}

The empirical analysis is based on data from the Italian Survey on Household Income and Wealth (SHIW), a biannual survey that collects detailed information on household income, savings and portfolios from a nationally representative sample of Italian households.

Households' financial assets are defined as the sum of deposits, securities, and commercial credits. Several covariates (age, gender, education) refer to the household head, defined as the household member who is responsible for economic and financial decision. We observe financial literacy of the household head only. Our baseline empirical analysis is based on the 2010 wave, because it includes both questions about the reasons for choosing the bank (available only in this year) and questions

\footnotetext{
${ }^{9}$ This paragraph is based on information provided by: i) Professor Paolo Legrenzi, who was President of the Commission for the financial communication of the PattiChiari Consortium until 2012; and ii) Valentina Panna and Luca Napoleoni, from the PattiChiari Consortium.

10 After considering all merges and acquisitions among banks over the relevant period, we find that only $1.5 \%$ of households in our baseline sample remained with a bank that changed affiliation with the PattiChiari Consortium. In all these cases these banks exited the Consortium after belonging to it for a period between 6 months and 5 years.
} 
to measure financial literacy. In Section 7 , we check the validity of the results in a larger sample, that also includes 2006 and 2008 waves: results are fully consistent.

The set of questions on financial literacy are included since 2006 and vary slightly across waves. In the 2010 wave, respondents are asked three questions related to portfolio diversification, the risk associated to fixed or adjustable interest rate and the effect of inflation ${ }^{11}$ Questions about diversification and inflation are similar to the ones devised for the US Health and Retirement Study (HRS henceforth) (Lusardi and Mitchell, 2011a) while knowledge of mortgage repayment mechanisms is not considered in the HRS. All these questions follow the principles of simplicity, relevance, brevity and capacity to differentiate identified by Lusardi and Mitchell (2011c).

We measure financial literacy with the number of questions correctly answered by the household head, but our results are robust to the use of different measures of financial literacy (see Section 7). Table 1 shows that in 2010 almost three out of four respondents answered correctly to the question on inflation; the percentage of correct answers to the question on mortgages and portfolio diversification is, respectively, $64 \%$ and 55\%. On average, respondents answered correctly to less than two questions, and one respondent out of three correctly answered to all questions.

We use information on the date of entrance and exit of each Italian banking group in the PattiChiari Consortium and the answer to questions about the banks used by the household to build an indicator of whether the household is client of a bank that is part of the PattiChiari Consortium. Our baseline analysis focuses on households having at least one bank account. We define a bank to be belonging to the Consortium in year $t$ if the bank was part of it by December $31^{\text {st }}$ of the previous year. In SHIW, each household may report their "main" bank -as defined by the household head- and up to seven additional banks where they hold a current account. Answers can be chosen from a list of 87 financial institutions (encompassing more than $85 \%$ of total credit granted in Italy). If the bank is not listed among the possible answers, its name will be missing. For each household, we construct a dummy $(p c)$ that is equal to one if the main bank used by the respondent belong to the Consortium and zero if it does not and we exclude households that do not have any bank account or for which the name of the bank is missing: $73 \%$ of respondents in our sample are clients of a bank that belongs to PattiChiari Consortium (Table 1 (12

\footnotetext{
${ }^{11}$ See Appendix A for the exact wording of the questions we consider and details on differences across waves.

${ }^{12} \mathrm{We}$ also considered a different definition and sample. We re-run the baseline regression also on the sample that includes records for which the name of the bank is missing and we consider banks with missing names to signal a
} 
Table 1: Descriptive Statistics.

\begin{tabular}{|c|c|c|c|}
\hline Variable & Mean & Std. Dev. & $\mathbf{N}$ \\
\hline Financial literacy (number of correct answers out of three) & 1.93 & 0.98 & 4865 \\
\hline Financial literacy, binary indicator 1 (three out of three answers correct) & 0.34 & 0.47 & 4865 \\
\hline Financial literacy, binary indicator 1(question on inflation correct) & 0.74 & 0.44 & 4865 \\
\hline Financial literacy, binary indicator 1(question on loan correct) & 0.64 & 0.48 & 4865 \\
\hline Financial literacy, binary indicator 1 (question on portfolio diversification correct) & 0.55 & 0.5 & 4865 \\
\hline Financial literacy (number of correct answers out of two present in 2006 \& 2008) & 1.38 & 0.71 & 4865 \\
\hline Instrumental variable, binary indicator 1 (Household is PattiChiari client) ( $p c$ ) & 0.73 & 0.45 & 4865 \\
\hline Financial assets (thousands) & 19.4 & 22.4 & 4865 \\
\hline Planning for retirement & 0.46 & 0.50 & 2653 \\
\hline Stock market participation & 0.12 & 0.32 & 4865 \\
\hline Male household head & 0.56 & 0.50 & 4865 \\
\hline Married & 0.64 & 0.48 & 4865 \\
\hline Nb. hh components & 2.47 & 1.21 & 4865 \\
\hline Years of education of the household head & 9.81 & 4.46 & 4865 \\
\hline Household labor income & 26.3 & 16.3 & 4865 \\
\hline Municipality 20.000-40.000 inh. & 0.26 & 0.44 & 4865 \\
\hline Municipality 40.000-500.000 inh. & 0.44 & 0.50 & 4865 \\
\hline Municipality 500.000+ inh. & 0.10 & 0.30 & 4865 \\
\hline High trust* & 0.56 & 0.50 & 4865 \\
\hline Length of relationship with the bank: less 2 years & 0.04 & 0.18 & 4757 \\
\hline Length of relationship with the bank: $2-4$ years & 0.07 & 0.26 & 4757 \\
\hline Length of relationship with the bank: $5-10$ years & 0.16 & 0.37 & 4757 \\
\hline Length of relationship with the bank: more than 10 years & 0.73 & 0.45 & 4757 \\
\hline Number of current accounts & 1.2 & 0.46 & 4865 \\
\hline \multicolumn{4}{|l|}{ Motivations for choosing the main bank ${ }^{* * *}$} \\
\hline Only one reason: related to convenience & 0.54 & 0.50 & 4865 \\
\hline Only one reason: related to financial/economic reason & 0.07 & 0.25 & 4865 \\
\hline Only one reason: related to bank characteristics & 0.02 & 0.15 & 4865 \\
\hline Two reasons: both related to convenience & 0.12 & 0.32 & 4865 \\
\hline Two reasons: related to convenience \& financial/economic reasons & 0.10 & 0.30 & 4865 \\
\hline Two reasons: related to convenience \& bank characteristics & 0.10 & 0.31 & 4865 \\
\hline Two reasons: both related to financial/economic reasons & 0.03 & 0.16 & 4865 \\
\hline Two reasons: financial/economic reasons \& bank characteristics & 0.02 & 0.15 & 4865 \\
\hline Two reasons: both related to bank characteristics & 0.00 & 0.05 & 4865 \\
\hline \multicolumn{4}{|l|}{ Sources of information ${ }^{* * * *}$} \\
\hline Only intermediaries or experts & 0.657 & 0.475 & 1492 \\
\hline Only press or websites & 0.016 & 0.126 & 1492 \\
\hline Only friends, others, do not know & 0.26 & 0.439 & 1492 \\
\hline
\end{tabular}

Notes: Unless otherwise stated all descriptive statistics refer to the 2010 stimation sample.

* Our measure of trust relies on the answer to the question "Do you trust your principal bank? Please assign a score of 1 to 10 , where 1 means 'I don't trust it at all' and 10 means 'I trust it completely' and the intermediate scores serve to graduate your response". Respondents who trust their main bank are those who choose a value above the median of the distribution of answers (8).

** Recoded from the categorical variable collected in the survey: for each category we impute the mid-point.

*** Each respondent can give at most two answers to the question on why the main bank is chosen. The 13 alternatives among which the respondent can choose are grouped into 3 broad categories: convenience (convenience to home/work, respondent's employer's bank (or respondent's business's bank)), financial/economic reasons (favourable interest rates, speed of transaction execution, range of services, low fees for services, possibility of online banking) and bank type (it is a well-known, important bank, staff courtesy). The figures show the percentage of respondents who choose only one alternative, two alternatives in the same group or two alternatives in different categories

Based on the question about the information source consulted before the current investments were performed. Available only for households who hold financial assets other than bank accounts. The figures show the average number of respondents who rely only on that specific source
of financial information. 
We include in the sample households whose head is aged 30 or above because we want to exclude cases in which individuals may be still enrolled in full-time education (at the university) and thus not financially independent from the family of origin. After excluding from our sample outliers and respondents who do not report the reason for choosing the bank, the final sample size in our baseline regression (2010 wave data) is 4865 observations (descriptive statistics are shown in Table (1) 13

For some complementary analysis we merge this data with data from the 2002 SHIW wave: due to the rotating panel of the survey, only 1027 households have been interviewed in 2002 and 2010. Notably, no measure of financial literacy is available in the 2002 SHIW wave.

We use data from a nationally representative sample of bank accounts (the Survey on Bank Fees and Expenditures, SBFE hereafter) to check that the fees and costs charged by PattiChiari and non-PattiChiari banks are on average similar. This dataset, administered by the Bank of Italy's Banking and Financial Supervision Area, is currently the most comprehensive source of information on bank costs in Italy and it collects information on fixed bank account costs, debit/credit card fees, costs of bank transfers and withdrawals. We rely on data on 6717 current accounts surveyed in SBFE and belonging to banks present in the SHIW dataset.

\section{Empirical Strategy}

To identify the effect of bank information policies on financial literacy, we consider the following linear model:

$$
f l_{i p}=\alpha_{0}+\alpha_{1} p c_{i p}+X_{i p} \alpha_{2}+\delta_{p}+\nu_{i p}
$$

where $f l_{i p}$ is financial literacy of the head of household $i$ living in province $p$ in 2010; $p c_{i p}$ is a dummy equal to 1 if the household is client of a bank belonging to the PattiChiari Consortium;

non-PattiChiari bank. Then, we create a dummy taking the value one if at least one of the accounts recorded in the survey is with a PattiChiari bank, and zero otherwise. We expect this indicator to have some degree of attenuation bias with respect to our main indicator, because some of the banks for which the name is unavailable may belong to the Consortium. All results reported in the paper are confirmed using this alternative indicator. Results are available from the authors upon request.

${ }^{13}$ We exclude the upper and lower $5 \%$ tail of the financial assets distribution. Results are similar with $1 \%$ trimming. There are tied values and we discuss this point in more detail in Section 7.5 
$X_{i p}$ is a vector of individual-level observable characteristics ${ }^{14} \delta_{p}$ is a province fixed-effect (province effects are denoted by $\mu_{p}$ or $\gamma_{p}$ in equations (2) and (3), respectively).

Similarly, to estimate the effect of bank information policies on financial assets, we consider equation (2):

$$
w_{i p}=\theta_{0}+\theta_{1} p c_{i p}+X_{i p} \theta_{2}+\mu_{p}+\xi_{i p}
$$

where $w_{i p}$ is household's financial assets in 2010 .

The main parameters of interest are $\alpha_{1}$ and $\theta_{1}$ : they capture the effect of being client of a bank in the PattiChiari Consortium on financial literacy and financial assets, respectively. Provided that $p c_{i p}$ is exogenous in equation (1) and (2), OLS estimates of these parameters are consistent and have a causal interpretation. We expect $\alpha_{1}$ and $\theta_{1}$ to be statistically significant and positive and we argue that the variable $p c_{i p}$ is exogenous in both equations. Investing in financial literacy is costly for individuals and the investment decision is made comparing marginal cost and marginal benefits (Jappelli and Padula, 2013b), where the latter may depend on financial wealth $w$ and individuals' characteristics $X$. We argue that the Quality Committments undertaken by a PattiChiari bank lower the cost of acquiring financial education without directly affecting the benefits related to additional financial literacy. Thus, other things being equal, we expect PattiChiari clients to acquire a higher stock of financial literacy. For this interpretation to be valid, the following three assumptions must be fulfilled. First, net of information policies, banks belonging to the PattiChiari Consortium may not differ from other banks with respect to characteristics that may directly affect household financial assets (such as costs and fees charged, credit rationing, mortgage policies, etc.). Second, individuals must not self-select as clients of a specific bank according to its information policy. In other words, the choice of the bank must not depend on variables that, conditional on province (or municipality) of residence, directly affect financial literacy or wealth. Third, banks must not join the Consortium in order to attract clients that are wealthier or more financially literate. These three assumptions are partly testable on the basis of the data at our hands and deserve a careful discussion.

\footnotetext{
${ }^{14}$ In the baseline specification, controls include gender of the household head, a second-order polynomial in age, years of education of the household head, household current labor income, household size, marital status, size of the municipality (3 categories: 20,000-40,000; 40,000-500,000; more than 500,000 inhabitants). We experimented with several subsets of these controls, and the inclusion of additional covariates is discussed in Section 6
} 


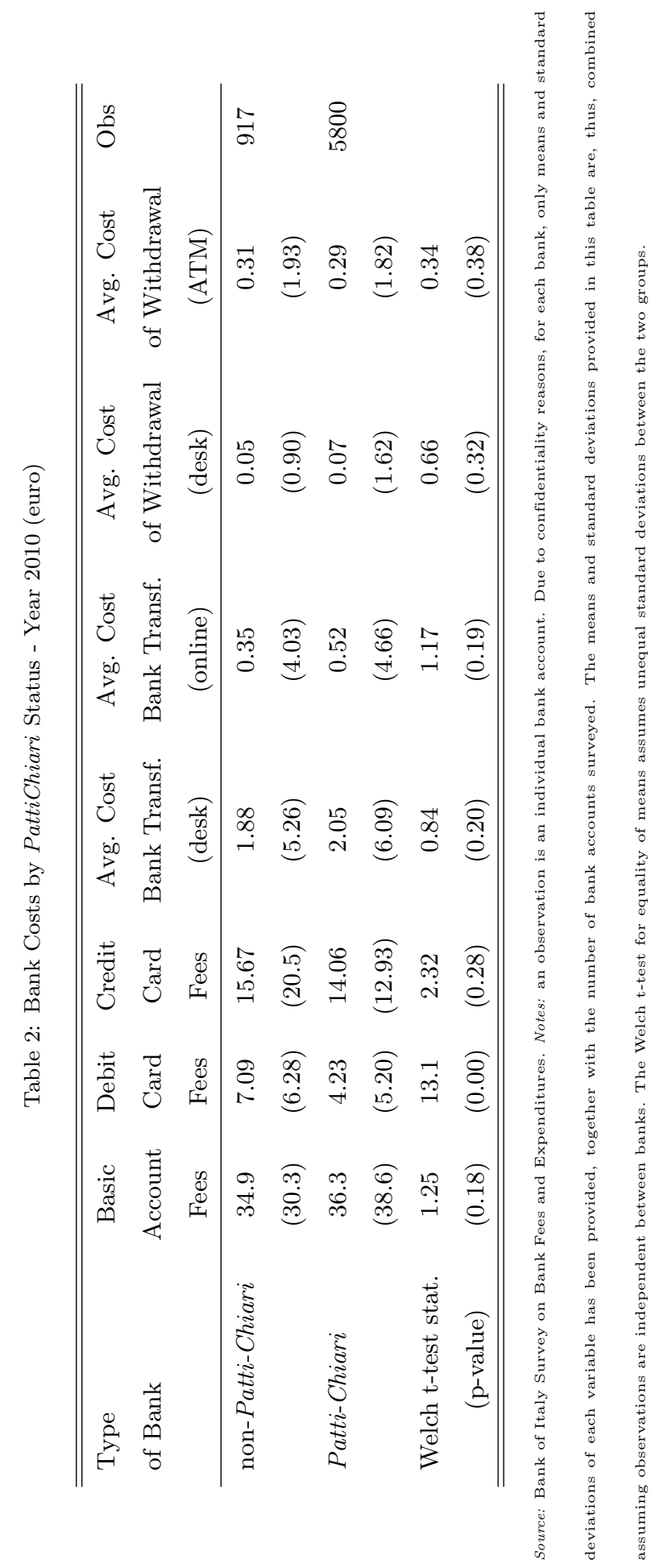


To support the first assumption we collect evidence showing that: a) fees and costs charged by PattiChiari and non-PattiChiari banks are generally not statistically different; b) there are no significant differences in credit rationing between PattiChiari and non-PattiChiari banks. Descriptive statistics on costs on bank accounts charged by banks belonging and not belonging to the PattiChiari Consortium are reported in Table 2, together with a Welch test on equality between means of the two groups. Differences in costs and fees are generally not statistically significant, the only exception being average debit card fees that are slightly larger (less than 3 euros per year) for non-PattiChiari banks. Our main results are unaffected by the inclusion of these costs among the control variables (see Section 6). We check whether banks that belong to the PattiChiari Consortium differ from other banks with respect to credit rationing, exploiting information about liquidity constraints provided by SHIW ${ }^{15}$ We do not find evidence of any correlation between being PattiChiari client and being liquidity constrained, that may signal differences in credit rationing, at standard significance levels. 16

Second, we provide empirical evidence suggesting that households do not self-select as PattiChiari clients based on financial offerings or to get more information from the bank. To explore the determinants of household choices, we rely on answers to the following question "Why did you choose [the bank you use more often] when you and your household first began using it?". Their answers can be naturally grouped in the following three categories: 1) convenience, i.e. convenience to home/work, respondent's employer's bank (or respondent's business's bank); 2) financial/economic reasons, i.e. favourable interest rates, speed of transaction execution, range of services, low fees for services, possibility of online banking; 3) bank type, i.e. it is a well-known/ important bank, staff courtesy. The main reason for choosing a bank is related to convenience, that is the only determinant for $63 \%$ of PattiChiari clients and for $67 \%$ of other respondents. Financial conditions are the only determinant for less than $15 \%$ of the respondents in both groups. We interpret this

\footnotetext{
${ }^{15}$ Following Jappelli et al. (1998), we consider a household to be "liquidity constrained" if it either (a) applied to a bank or a financial company to ask for loan or mortgages and the application was rejected, or (b) considered the possibility to apply but did not, thinking that the application would have been rejected.

${ }^{16}$ At average values of the covariates, the marginal effect of being PattiChiari client on the probability of being liquidity constrained is -0.005 with a standard error of 0.007 . The model controls for province fixed effects, municipality size, and individual observable characteristics (quadratic polynomial in age, gender, marital status, household size, education, family labor income and reason for choosing the main bank).
} 
evidence as follows: the availability of preferred financial offerings may be readily available and consumers typically decide their bank depending on the one that is more conveniently located to them. In other words, the constraint on financial services is not binding and it is satisfied by the abundance of options, hence individuals choose on the basis of their second (binding) constraint, i.e. convenience. As we discuss in more detail in Section 6, our results are unaffected by the inclusion of these controls in our baseline regression, while precision of the estimates is improved. It is worth noting that, if banks are mainly chosen because of proximity, one should observe a high correlation between the proportion of PattiChiari clients in a specific province and the proportion of PattiChiari banks branches. Indeed, the correlation between these two variables is positive and ranges from 0.4 to 0.7 according to the different definitions of being a PattiChiari client that we consider in the paper.

Transparency or, more generally, information acquisition is not mentioned among the alternative reasons for choosing the bank. For this reason, one may argue that we cannot rule out the possibility that clients join a PattiChiari bank to get more information. To address this issue we exploit one question - asked to household with financial assets other than bank accounts - about the sources of financial information consulted before buying some financial products. In Section 7 . we check whether controlling for sources of financial information affects our findings. In short, in the sub-sample where we can perform this sensitivity check: i) there is no direct effect of sources of financial information on financial assets other than through financial literacy; ii) the reduced form (first-stage and intention-to-treat) and instrumental variable estimates are not confounded by the direct effect of sources of financial information. We interpret this evidence as additional support for the internal validity of our identification strategy. All in all, it looks that, ex-ante, customers are not aware of the distinction between PattiChiari and non- PattiChiari banks.

To support the third assumption, we collect complementary evidence documenting that individuals do not self-select as client of a bank belonging to the PattiChiari Consortium according to their wealth. For this purpose, we exploit the panel component of the SHIW dataset to retrieve information on household financial assets in 2002, i.e. before the PattiChiari Consortium was created. First, we perform a "placebo" test, regressing 2002 assets on being a PattiChiari client in 2010. We fail to find a significant correlation between being such a client in 2010 and 2002 assets 17

\footnotetext{
${ }^{17}$ The coefficient associated to the PattiChiari dummy in this test regression is 12.663 with a standard error of
} 
Second, we use financial assets in 2002 as a control in equation (2). Consistently with the "placebo" result, estimates are not affected by the inclusion of this additional control ${ }^{18}$

In the paper, we also examine the effect of financial literacy on financial assets by considering the model:

$$
w_{i p}=\beta_{0}+\beta_{1} f l_{i p}+X_{i p} \beta_{2}+\gamma_{p}+\varepsilon_{i p} .
$$

OLS estimates of $\beta_{1}$ in Equation (3) may be biased because of: (i) individual unobserved heterogeneity (i.e. ability, patience or preferences) correlated with both financial literacy and the value of financial assets; (ii) reverse causality; (iii) measurement error. In the first case, the sign of the bias is theoretically ambiguous and depends on the sign of the correlation between $f l_{i p}$ and $\varepsilon_{i p}$ in equation (3). The theoretical arguments in Jappelli and Padula (2013b) suggest that reverse causality should lead to an upper bias in the estimate of $\beta_{1}$, since individual wealth may affect the incentive to increase financial education both through a change in the opportunity-cost of time and through a change in the relative benefit from knowing how financial tools work 19 Finally, measurement error in financial literacy may be substantial because respondents may guess the answer at random or they may misunderstand the question ${ }^{20}$ In these cases, OLS estimate may be biased downward (Jappelli and Padula, 2013b). Overall, these remarks suggest that: (i) OLS estimates may be biased and (ii) the sign of the bias cannot be assessed theoretically since it depends on the relevance of each of the channels described above. To address these issues, we pursue an instrumental variable approach and use equation (1) as the first stage equation for the financial asset equation $3 \sqrt{21}$

The instrumental variable strategy relies on the three assumptions discussed above, since it

13.847 .

${ }^{18}$ These results are available from the authors upon request.

19 Lusardi and Mitchell (2007), however, present empirical results that suggest that reverse causality is not a relevant issue in American data (HRS).

${ }^{20}$ Evidence from the U.S. (Lusardi and Mitchell, 2009) and the Netherlands van Rooij et al. 2011b) suggests that survey data on this issue are sensitive to how the question is worded.

21 With panel data, household fixed effects could be included in equation (3). There are three arguments against this choice. First, financial assets and financial literacy are both highly stable over the short time span we consider (2006-2010) in this application. Second, respondents may learn from previous interviews: the variation in correct answers may capture recalling rather than increases in financial literacy. This would affect estimates delivered by a fixed effect identification approach, while it does not drive our results, as we show in Section 7 Third, using the longitudinal panel would cut sample size by half because of attrition and survey design. It is worth noting that in case of reverse causality or measurement error coefficients in equation 3 are biased also when including fixed effects. 
rests on consistent estimation of $\alpha_{1}$ and $\theta_{1}$ with OLS and an exclusion restriction Angrist et al. 1996). As a final piece of evidence in favor of our exclusion restriction - namely, the assumption that being PattiChiari affects financial assets only through its effects on financial literacy - in Section 7 we exploit the panel dimension of the dataset to construct a set of instruments based on the information of individuals who change their main bank account, moving in and out the PattiChiari Consortium, and we perform an over-identification test. We find evidence supporting the exogeneity of our instrument (i.e. being client of a PattiChiari bank) in the financial assets equation (see Section 7.4.

\section{Findings}

Estimate results of the baseline specification are shown in Table 3 . Along with household covariates and province fixed effects, it includes controls for motivations for choosing the bank 22 Excluding these controls does not affect the point estimate of the PattiChiari dummy nor the one of the key variables of interest ${ }^{23}$ The association between financial literacy and financial assets is positive (column OLS in Table 3): our estimates suggest that one standard deviation increase in financial literacy (i.e. one more correct answer) is associated with an increase in financial assets by more than 2 thousand euros (about $12 \%$ of the average financial assets holdings in our baseline sample). As discussed in Section 5, this estimate is unlikely to reflect a causal relationship but represent an important benchmark for our analysis.

Being a client of a PattiChiari bank leads an individual to give 0.24 additional correct answers, that is approximately one fourth of a standard deviation of financial literacy, nearly $12 \%$ of the average number of correct answers given in the sample (see column FS in Table 3). The effect of banks information policies on financial literacy is sizeable compared to other explanatory variables in our regressions: the impact of being client of a bank that belong to the PattiChiari Consortium is

\footnotetext{
${ }^{22}$ Unless otherwise stated, estimated standard errors are robust to both heteroskedasticity and serial correlation at the province level, the largest level at which we have enough clusters (103) to obtain consistent estimates of the second moment of the estimator distribution.

${ }^{23}$ If we do not control for motivations for choosing the main bank, the OLS and IV estimates (standard errors) of the coefficients for financial literacy are, respectively, $2.293^{* * *}(0.637)$ and $8.802^{* * *}(3.243)$. The coefficients for the PattiChiari dummy in the FS and ITT are, respectively, $0.219^{* * *}(0.034), 1.925^{* *}(0.752)$. The F-test on the excluded instrument in the first stage equation is 41.751 .
} 
comparable to the effect of increasing education by five years ${ }^{24}$ The F-test on excluded instruments is around 44, showing that, when we interpret this equation as the first step of our IV strategy, the instrument is not weak 25

This finding is robust to alternative measures of financial literacy. We consider four alternative definitions: a dummy equal to 1 if all three questions have been answered correctly and zero otherwise or we consider the correct answers of each of these three questions separately. Being a PattiChiari client is strongly correlated with all these definitions and leads to about $13 \%$ increase in the probability of answering all questions correctly, $14 \%$ increase in the probability of answering correctly the question on inflation and an $11 \%$ increase in the probability of answering the loan or portfolio question correctly, with respect to the sample average (see Table $1{ }^{26}$ Using dichotomous variables for financial literacy also allows to measure the proportion of the so-called compliers (Angrist et al. 1996), i.e. individuals whose knowledge of financial instruments increases because of the information policies of the PattiChiari banks. They represent a small fraction of our sample, ranging between $5 \%$ and $10 \%$ of the population.

Having the main current account in a PattiChiari bank raises household financial assets by about 1.9 thousand euros, roughly $10 \%$ of the average value of assets in our sample (column ITT in Table 3). The resulting instrumental variable estimates (column IV of Table 3) are larger than what simple association suggests: on average, a one standard deviation increase in financial literacy (i.e.

\footnotetext{
24 As discussed in Section 2 evidence on the causal impact of interventions on financial literacy is still limited.
} Assessing the effect of banks information policies relative to other interventions is, therefore, not straightforward. Klapper and Panos 2011) consider the role of newspapers in Russia: their findings suggest that a $2 \%$ increase in the number of newspapers leads to a increase of financial literacy of nearly $8 \%$, while a $7 \%$ increase in the number of universities leads to only a 1\% increase in financial literacy. Carpena et al. (2011) assess the effect of a video-based financial literacy program in India. The authors document negligible effects on numeracy skills and about $8 \%$ increase in financial awareness. The relative size of the effect we find seems, thus, slightly larger than the one of previous information/training instruments in Russia and India.

25 Staiger and Stock 1997) indicate a rule of thumb suggesting that the F-statistic should be greater than 10 to rule out weak identification problems.

${ }^{26}$ The estimates of the coefficients associated to our indicator of being PattiChiari client are: 0.045 (F-test: 8.152 ) when we consider the binary indicator for three questions correct; 0.102 (F-test: 29.128) when we use the binary indicator for the question on inflation correct ; 0.071 (F-test: 28.297) when we use the binary indicator for the loan question correct and finally 0.062 (F-test: 10.715) when we use the indicator for the portfolio diversification question correct. 
an additional correct answer provided, about a 50\% increase with respect to the average financial literacy), conditional on other covariates, leads to an increase of household assets of 8 thousand euros ${ }^{27}$ Thus, in line with findings by Lusardi and Mitchell (2011b), the causal effect of financial literacy is around four times higher than suggested by the corresponding association. The downward bias in OLS estimate can be explained by a negative correlation between financial literacy and the error term in the financial assets equation or by the presence of substantial measurement error in financial literacy. The latter argument would be consistent with evidence on the sensitivity of answers to financial literacy questions documented by Lusardi and Mitchell $(2009)$ for the US and by van Rooij et al. (2011b) for the Netherlands.

Looking at the effect of other regressors, results in Table 3 show that financial assets are increasing and concave in age, and depend on household composition (being married and the household size). As expected, financial assets increases with family labor income and education.

All results remain unchanged when we enrich the baseline specification with additional controls for household's main bank cost:28 or if we use an alternative measure of being a PattiChiari client (results available from the authors upon request).

In the baseline regression we control for province fixed effect. But municipality-specific factors may affect both the level of financial assets and the probability of being client of a PattiChiari bank (e.g. different banks may decide to open branches in a particular type of municipality). We include municipality-fixed effects and replicate our baseline results: previous findings are confirmed 29

\footnotetext{
${ }^{27}$ This effect apply to the sub-population of individuals whose knowledge of financial instruments increases because of the information policies of the PattiChiari banks and cannot be generalized to the average sample household without further assumptions (Angrist 2004).

${ }^{28}$ The OLS, FS, ITT, and IV estimates are respectively: $2.268^{* * *}(0.657), 0.231^{* * *}(0.040), 2.057^{* * *}(0.789)$, $8.917^{* * *}(3.481)$. The F-test on the excluded instrument in the first stage equation is 33.318 . The regression includes the same controls as the baseline and controls for cost of transfer (desk and online) and cost of withdrawal (desk or ATM).

${ }^{29}$ Italian provinces are on average composed of about 74 municipalities each. The estimated OLS and IV coefficients for financial literacy in the equation for financial assets (and their standard errors) are, respectively, $2.331^{* * *}(0.510)$; IV $12.051^{* * *}$ (4.275). The effect of being a client of a PattiChiari bank in the FS and ITT equations are, respectively, $0.192^{* * *}(0.037)$ and $2.354^{* * *}(0.732)$. The full set of results are available upon request.
} 
Table 3: Effect of Financial Literacy on Financial Assets. Financial literacy is the number of correct answers out of the three questions asked in 2010. 2010 SHIW Data.

\begin{tabular}{|c|c|c|c|c|}
\hline Financial literacy & $\begin{array}{l}\text { OLS } \\
2.231 * * * \\
(\mathbf{0 . 6 3 0})\end{array}$ & FS & ITT & $\begin{array}{l}\mathrm{IV} \\
8.273^{* * *} \\
(\mathbf{2 . 9 7 9 )}\end{array}$ \\
\hline Client of PattiChiari & & $\begin{array}{l}0.235 * * * \\
(0.035)\end{array}$ & $\begin{array}{c}1.941^{* * *} \\
(0.723)\end{array}$ & \\
\hline Age & $\begin{array}{l}0.832^{* * *} \\
(0.136)\end{array}$ & $\begin{array}{l}0.054^{* * *} \\
(0.006)\end{array}$ & $\begin{array}{l}0.939^{* * *} \\
(0.134)\end{array}$ & $\begin{array}{l}0.494^{* *} \\
(0.197)\end{array}$ \\
\hline Age squared & $\begin{array}{l}-0.005^{* * *} \\
(0.001)\end{array}$ & $\begin{array}{l}-0.000^{* * *} \\
(0.000)\end{array}$ & $\begin{array}{l}-0.006^{* * *} \\
(0.001)\end{array}$ & $\begin{array}{l}-0.001 \\
(0.002)\end{array}$ \\
\hline Male & $\begin{array}{l}1.017 \\
(0.642)\end{array}$ & $\begin{array}{l}0.170^{* * *} \\
(0.025)\end{array}$ & $\begin{array}{l}1.347^{* *} \\
(0.652)\end{array}$ & $\begin{array}{l}-0.063 \\
(0.705)\end{array}$ \\
\hline Married & $\begin{array}{l}2.479^{* * *} \\
(0.625)\end{array}$ & $\begin{array}{l}0.024 \\
(0.037)\end{array}$ & $\begin{array}{l}2.497^{* * *} \\
(0.645)\end{array}$ & $\begin{array}{l}2.295^{* * *} \\
(0.596)\end{array}$ \\
\hline Nb. hh components & $\begin{array}{l}-1.501^{* * *} \\
(0.292)\end{array}$ & $\begin{array}{l}0.051^{* * *} \\
(0.017)\end{array}$ & $\begin{array}{l}-1.391^{* * *} \\
(0.292)\end{array}$ & $\begin{array}{l}-1.812^{* * *} \\
(0.342)\end{array}$ \\
\hline Years education & $\begin{array}{l}0.918^{* * *} \\
(0.095)\end{array}$ & $\begin{array}{l}0.045^{* * *} \\
(0.004)\end{array}$ & $\begin{array}{l}0.999 * * * \\
(0.091)\end{array}$ & $\begin{array}{l}0.626^{* * *} \\
(0.178)\end{array}$ \\
\hline Municipality 20.000-40.000 inhabitants & $\begin{array}{l}1.040 \\
(1.415)\end{array}$ & $\begin{array}{l}0.071 \\
(0.070)\end{array}$ & $\begin{array}{l}1.256 \\
(1.456)\end{array}$ & $\begin{array}{l}0.673 \\
(1.388)\end{array}$ \\
\hline Municipality 40.000-500.000 inhabitants & $\begin{array}{l}0.212 \\
(1.086)\end{array}$ & $\begin{array}{l}-0.009 \\
(0.088)\end{array}$ & $\begin{array}{l}0.157 \\
(1.114)\end{array}$ & $\begin{array}{l}0.235 \\
(1.173)\end{array}$ \\
\hline Municipality 500.000+ inhabitants & $\begin{array}{l}-0.308 \\
(2.061)\end{array}$ & $\begin{array}{l}0.151 \\
(0.165)\end{array}$ & $\begin{array}{l}-0.027 \\
(2.024)\end{array}$ & $\begin{array}{l}-1.275 \\
(2.679)\end{array}$ \\
\hline Household labor income & $\begin{array}{l}0.414^{* * *} \\
(0.033)\end{array}$ & $\begin{array}{l}0.000 \\
(0.001)\end{array}$ & $\begin{array}{l}0.413^{* * *} \\
(0.034)\end{array}$ & $\begin{array}{l}0.409^{* * *} \\
(0.032)\end{array}$ \\
\hline Only one motivation: services & $\begin{array}{l}1.126 \\
(1.207)\end{array}$ & $\begin{array}{l}0.092 \\
(0.060)\end{array}$ & $\begin{array}{l}1.647 \\
(1.204)\end{array}$ & $\begin{array}{l}0.887 \\
(1.310)\end{array}$ \\
\hline Only one motivation: bank characteristics & $\begin{array}{l}1.804 \\
(1.870)\end{array}$ & $\begin{array}{l}-0.108 \\
(0.067)\end{array}$ & $\begin{array}{l}1.489 \\
(1.847)\end{array}$ & $\begin{array}{l}2.382 \\
(1.970)\end{array}$ \\
\hline Two motivations: two convenience & $\begin{array}{l}4.626^{* * *} \\
(1.258)\end{array}$ & $\begin{array}{l}0.056 \\
(0.052)\end{array}$ & $\begin{array}{l}4.774^{* * *} \\
(1.292)\end{array}$ & $\begin{array}{l}4.314^{* * *} \\
(1.165)\end{array}$ \\
\hline Two motivations: convenience \& financial conditions & $\begin{array}{l}1.312 \\
(1.155)\end{array}$ & $\begin{array}{l}0.132^{*} \\
(0.069)\end{array}$ & $\begin{array}{l}1.786 \\
(1.173)\end{array}$ & $\begin{array}{l}0.698 \\
(1.208)\end{array}$ \\
\hline Two motivations: convenience \& bank characteristics & $\begin{array}{l}4.595^{* * *} \\
(1.306)\end{array}$ & $\begin{array}{l}0.067 \\
(0.057)\end{array}$ & $\begin{array}{l}4.665^{* * *} \\
(1.303)\end{array}$ & $\begin{array}{l}4.113^{* * *} \\
(1.261)\end{array}$ \\
\hline Two motivations: two financial conditions & $\begin{array}{l}2.818 \\
(1.741)\end{array}$ & $\begin{array}{l}0.184^{* *} \\
(0.077)\end{array}$ & $\begin{array}{l}3.470^{*} \\
(1.832)\end{array}$ & $\begin{array}{l}1.949 \\
(1.608)\end{array}$ \\
\hline Two motivations: financial conditions \& bank characteristics & $\begin{array}{l}1.644 \\
(2.232)\end{array}$ & $\begin{array}{l}0.139 \\
(0.087)\end{array}$ & $\begin{array}{l}2.013 \\
(2.242)\end{array}$ & $\begin{array}{l}0.862 \\
(2.228)\end{array}$ \\
\hline Two motivations: two bank characteristics & $\begin{array}{l}4.698 \\
(3.831)\end{array}$ & $\begin{array}{l}0.037 \\
(0.172)\end{array}$ & $\begin{array}{l}4.701 \\
(3.869)\end{array}$ & $\begin{array}{l}4.391 \\
(3.844)\end{array}$ \\
\hline Province FE & Yes & Yes & Yes & Yes \\
\hline $\begin{array}{l}\mathrm{N} \\
\text { Ftest }\end{array}$ & 4865 & 4865 & 4865 & $\begin{array}{l}4865 \\
43.849\end{array}$ \\
\hline
\end{tabular}

Notes: the table reports OLS, first-stage, intention-to-treat, and instrumental variable results of the model $w_{i p}=\widetilde{\alpha}+\widetilde{\beta} f l_{i p}+X_{i p} \widetilde{\gamma}+\lambda_{p}+\varepsilon_{i p}$ where $w_{i p}$ is financial assets owned by household $i$, living in province $p$, in year 2010; $f l_{i p}$ is financial literacy of the household head, $X_{i p}$ is a vector of household controls, and $\lambda_{p}$ is a province fixed effect. Financial literacy is instrumented with a dummy that takes the value 1 if the household's main bank belongs to the PattiChiari Consortium and 0 otherwise. Heteroskedasticity-robust standard errors clustered at the province level in parentheses. ${ }^{*} p<0.1,{ }^{* *} p<0.05,{ }^{* * *} p<0.01$ 


\section{Robustness and Extensions}

In this section, we check the robustness our findings to several falsification checks. In particular, we explore: i) the role of retest effects and the timing of the effect of banks information policies and financial literacy; ii) the role of trust in institutions; iii) self-selection of clients into PattiChiari banks; iv) the sensitivity of our results to sample selection and the functional form. We then present the results of an over-identification test that supports the validity of the causal interpretation of the estimates presented in the previous section. Our results are robust to all these checks. We extend our analysis discussing what are the channels that may drive the effect measured when looking at the aggregate measure of financial assets and we explore the heterogeneity of our result with respect to household observed (and pre-determined) characteristics.

\subsection{The Role of Retest Effects and the Timing of the Effect of Banks Information Policies and Financial Literacy}

The SHIW dataset has a rotating panel sub-sample. Households that have been interviewed in previous surveys may recall the right answer to questions used to measure financial literacy and, thus, illiterate respondents may be classified as literate ones (retest effect). In addition, attrition in the panel sub-sample tends to be higher among worse-off households (Biagi et al., 2009). The simultaneous presence of retest effects and non-random attrition may upwardly bias our IV results. To test whether this bias is present, we check whether the effect of financial literacy is different for households who participated both in the 2008 and in the 2010 wave. In practice, we interact both the instrument and financial literacy variables with a dummy equal to 1 if the household was interviewed before 2010. Results -not reported here for brevity but available from the authors upon request- do not provide evidence of retest effects in the sample. Controlling for this channel does not alter the ITT and IV results: the interaction between being PattiChiari client and being interviewed more than once is never statistically significant. The estimated effect of financial literacy for respondents interviewed more than once is not statistically different from the one estimated for the rest of the sample.

A different albeit related concern refers to the timing of the effect of the treatment and of the instrumental variable. On the one hand, the year 2010 may not be a representative year to assess the role of financial literacy. Indeed, during the crisis (as the financial market shrinks and banks reduce markedly their credit to firms and households) having knowledge of financial instruments 
may represent a stronger advantage with respect to what happens during normal years. On the other hand, one may argue that the effect of banks information policies fades away (or becomes stronger) over time. Questions concerning financial literacy are included in the SHIW since the 2006 wave, but only 2 questions are common to all three waves (2006, 2008, and 2010): the one regarding knowledge of inflation mechanism and the one on different types of loan repayment schemes 30 We restrict our analysis to these common items and perform two different robustness checks. First, we interact year dummies with both the instrumental and the financial literacy variables. Results, reported in Table 4 show that the direct effect of PattiChiari and the causal effect of financial literacy on financial assets do not change overtime. Second, we exploit the panel component of the sample and we estimate the effect of being exposed to the PattiChiari information policy in 2008 or in 2006 on financial literacy in 2010 (Table 5). As the sample size sensibly decreases, the instrument is weaker with respect to the baseline results (Table 3). Our main variables of interest are, however, significant and the magnitude of the reduced form and instrumental variable estimates are slightly larger than those reported in Table 3 where we use being client of a PattiChiari bank in 2010 as instrument.

\subsection{The Role of Trust in Institutions}

As discussed in Section 5 , our identification strategy is based on the assumption that the choice of the bank is not correlated with factors that may affect wealth. Georgarakos and Inderst (2011) find that the level of trust in institutions and financial advisors may affect individual investment decision. We check whether including proxies for trust as additional controls alters our results. We exploit two different sources to identify trust in financial institutions: survey respondents are interviewed about trust in their main bank and about the length of the relationship with their main bank. In the first panel of Table 6, we add a dummy capturing whether the respondent trusts his/her main bank 31 The effect of this variable is not significant and the key results remain comparable to the baseline specification. In the second panel, we control for the length of the

\footnotetext{
${ }^{30}$ More details on this are provided in $\overline{\text { Appendix } \mathrm{A}}$

${ }^{31}$ Our measure of trust relies on the answer to the question "Do you trust your principal bank? Please assign a score of 1 to 10, where 1 means "I don't trust it at all" and 10 means "I trust it completely" and the intermediate scores serve to graduate your response". Respondents who trust their main bank are those who choose a value above the median of the distribution of answers (8); results are confirmed if we define the we set this binary indicator equal to one if the answer is above 5,0 otherwise.
} 
Table 4: Robustness: Heterogeneity of the Effect of Financial Literacy on Financial Assets across years, 2006-2010 SHIW Data (repeated cross-section). Financial literacy is the number of correct answers out of the two common across waves.

\begin{tabular}{|c|c|c|c|}
\hline & OLS & ITT & IV \\
\hline \multirow[t]{2}{*}{ Financial literacy } & 0.731 & & $16.404^{* * *}$ \\
\hline & $(0.734)$ & & $(4.973)$ \\
\hline \multirow[t]{2}{*}{ Financial literacy · $1($ year=2008) } & 0.602 & & -0.418 \\
\hline & $(0.704)$ & & $(3.693)$ \\
\hline \multirow[t]{2}{*}{ Financial literacy · $1($ year=2010) } & 0.898 & & -0.372 \\
\hline & $(0.848)$ & & $(4.037)$ \\
\hline \multirow[t]{2}{*}{ Client of PattiChiari } & & $2.621^{* * *}$ & \\
\hline & & $(0.822)$ & \\
\hline \multirow[t]{2}{*}{ Client of PattiChiari $\cdot 1($ year $=2008)$} & & -0.127 & \\
\hline & & $(0.983)$ & \\
\hline \multirow[t]{2}{*}{ Client of PattiChiari $\cdot 1($ year $=2010)$} & & -0.236 & \\
\hline & & $(1.098)$ & \\
\hline N. of observations & 11812 & 11812 & 11812 \\
\hline
\end{tabular}

Descriptive statistics -Avg (se)- on this sample

Financial Assets : 18.45 (21.35); Financial Literacy : 1.37 (0.74)

\footnotetext{
Notes: the table reports OLS, first-stage, intention-to-treat, and instrumental variable results of the model $w_{i p t}=\widetilde{\alpha}+\widetilde{\beta_{1}} f l_{i p t}+\widetilde{\beta_{2}} f l_{i p t} \cdot 1(t=$ $2008)+\widetilde{\beta_{3}} f l_{i p t} \cdot 1(t=2010)+X_{i p t} \widetilde{\gamma}+\lambda_{p t}+\varepsilon_{i p t}$ where $w_{i p t}$ is financial assets owned by household $i$, living in province $p$, in year $t ; f l_{i p t}$ is financial literacy of the household head measured as the number of correct answers over the two questions asked in 2006, 2008 and 2010; $1(\cdot)$ is the indicator function, $X_{i p t}$ is a vector of household controls (as in the baseline specification of Table 3 , and $\lambda_{p t}$ is a province-year fixed effect. Financial literacy and its interaction with year dummies are instrumented with a dummy that takes the value 1 if the household's main bank belongs to the PattiChiari Consortium in year $t$, interacted with year dummies, and 0 otherwise. Heteroskedasticity-robust standard errors clustered at the province level in parentheses.
} 
Table 5: Robustness: Timing of the Effect of Being PattiChiari Client. Measure of Financial Literacy: Number of Correct Answer over the Two Questions Common Across SHIW 2006 wave, 2008 wave and 2010 wave. SHIW panel individuals over 2006-2010.

\begin{tabular}{|c|c|c|c|c|}
\hline \multicolumn{5}{|c|}{ Data: Client of PattiChiari measured in 2008} \\
\hline Financial literacy & $\begin{array}{l}2.331^{* *} \\
(0.912)\end{array}$ & & & $\begin{array}{l}15.127^{* *} \\
(6.995)\end{array}$ \\
\hline Client of PattiChiari in 2008 & & $\begin{array}{l}0.222^{* * *} \\
(0.071)\end{array}$ & $\begin{array}{l}3.358^{* *} \\
(1.289)\end{array}$ & \\
\hline $\begin{array}{l}\text { N. of observations } \\
\text { F-test on the } \\
\text { excluded instruments }\end{array}$ & 1662 & 1662 & 1662 & $\begin{array}{l}1662 \\
9.72\end{array}$ \\
\hline \multicolumn{5}{|c|}{ Data: Data: Client of PattiChiari measured in 2006} \\
\hline Financial literacy & $\begin{array}{l}2.331^{* *} \\
(0.912)\end{array}$ & & & $\begin{array}{l}15.719^{* *} \\
(9.117)\end{array}$ \\
\hline Client of PattiChiari in 2006 & & $\begin{array}{l}0.168^{* *} \\
(0.076)\end{array}$ & $\begin{array}{l}2.642^{* *} \\
(1.149)\end{array}$ & \\
\hline $\begin{array}{l}\text { N. of observations } \\
\text { F-test on the } \\
\text { excluded instruments }\end{array}$ & 1662 & 1662 & 1662 & $\begin{array}{l}1662 \\
4.972\end{array}$ \\
\hline
\end{tabular}

Descriptive statistics -Avg (se)- on this sample

Financial Assets : 21.52 (23.58); Financial Literacy : 1.99 (0.92)

Notes: Elaborations based on the 2010 wave data on financial assets and financial literacy and lagged values of the instrumental variable as indicated in the tables; elaborations restricted to the households in the panel sub-sample. Measure of financial literacy: number of correct answers over the two questions common across SHIW 2006 wave, 2008 wave and 2010 wave.

All regressions include the controls in the baseline specification (Table 3 .

Errors robust to heteroskedasticity and clustered at the province level $\mathrm{in}$ parentheses.

${ }^{*} p<0.1,{ }^{* *} p<0.05,{ }^{* * *} p<0.01$. 
relationship between the client and the bank: we expect a longer relationship to reflect higher trust in the bank. This variable is correlated with level of financial assets (ITT and IV) but controlling for it does not affect the impact of the main variables of interest. The two proxies for trust in banks are not significantly different from zero in the first stage equation (FS columns in the top panels of Table 6 at conventional levels of significance. This evidence suggests that the effects of banks information policies (proxied by our binary indicator of being a PattiChiari client) on financial literacy are not mediated by trust.

\subsection{Evidence Against Self-Selection of Households into PattiChiari Banks}

Households who hold more than one bank account may be wealthier than the average and may already diversify their portfolios using services from different banks. As having more bank accounts increases the chances of being a PattiChiari client, this may generate spurious correlation. To control for this possibility, we include household's number of bank accounts in our baseline specification. Results, presented in the third panel of Table 6, show that our baseline findings remain practically unchanged.

Households that are wealthy or willing to use sophisticated financial products may prefer PattiChiari banks because of the information policies they provide. This potential problem of selfselection is particularly hard to test, as it entails gouging unobserved characteristics (propensity to invest) and potentially simultaneous choices (information seeking and bank choice). Nonetheless, some indirect evidence can be obtained by exploiting data on the source of financial information used by respondents to make investment decisions. In the 2010 SHIW survey, household heads are asked about the information source they have been consulted before the current investments were performed. Possible answers include "formal" source (financial intermediaries or advisors) and more "informal" ones (friends, relatives, and colleagues; specialized press or websites) and multiple answers are possible. These sources can be grouped in three broad categories: formal sources (financial intermediaries, experts and advisors) and two categories of informal ones, namely press or websites and the residual (friends, others, do not know). Descriptive statistics of the resulting indicators are reported in Table 1. Since this information is collected only for respondents who hold financial assets other than bank accounts ("investor households" hereafter), the sample size reduces to 1492 households, who are, on average, wealthier and more financially sophisticated than 
Table 6: Effect of Financial Literacy on Financial Assets, Adding Additional Controls to the Baseline Specification: Trust, Length of Relation with Bank or Number of Bank Accounts Held by the Household

\begin{tabular}{|c|c|c|c|c|}
\hline \multicolumn{5}{|l|}{ Additional control: Trust } \\
\hline Financial literacy & $\begin{array}{l}2.230^{* * *} \\
(0.627)\end{array}$ & & & $\begin{array}{l}8.258^{* * *} \\
(3.058)\end{array}$ \\
\hline Client of PattiChiari & & $\begin{array}{l}0.240^{* * *} \\
(0.036)\end{array}$ & $\begin{array}{l}1.981^{* * *} \\
(0.741)\end{array}$ & \\
\hline High trust & $\begin{array}{l}0.150 \\
(0.627)\end{array}$ & $\begin{array}{l}0.049 \\
(0.044)\end{array}$ & $\begin{array}{l}0.373 \\
(0.645)\end{array}$ & $\begin{array}{l}-0.032 \\
(0.746)\end{array}$ \\
\hline $\begin{array}{l}\text { F-test on the excluded instruments } \\
\text { N. of observations }\end{array}$ & 4865 & 4865 & 4865 & $\begin{array}{l}44.023 \\
4865\end{array}$ \\
\hline \multicolumn{5}{|c|}{ Additional control: Length of Relation with Bank } \\
\hline Financial literacy & $\begin{array}{l}2.099 * * * \\
(0.656)\end{array}$ & & & $\begin{array}{l}6.239^{* *} \\
(3.089)\end{array}$ \\
\hline Client of PattiChiari & & $\begin{array}{l}0.223^{* * *} \\
(0.037)\end{array}$ & $\begin{array}{l}1.393^{*} \\
(0.713)\end{array}$ & \\
\hline Length relation bank: more than 10 years & $\begin{array}{l}3.618^{* * *} \\
(0.895)\end{array}$ & $\begin{array}{l}0.069 \\
(0.044)\end{array}$ & $\begin{array}{l}0.3620^{* * *} \\
(0.884)\end{array}$ & $\begin{array}{l}3.191^{* * *} \\
(0.947)\end{array}$ \\
\hline F-test on the excluded instruments & & & & 35.721 \\
\hline N. of observations & 4757 & 4757 & 4757 & 4757 \\
\hline \multicolumn{5}{|c|}{ Additional control: Number of Bank Accounts Held by the Household } \\
\hline Financial literacy & $\begin{array}{l}2.195^{* * *} \\
(0.633)\end{array}$ & & & $\begin{array}{l}8.123^{* * *} \\
(2.997)\end{array}$ \\
\hline Client of PattiChiari & & $\begin{array}{l}0.234^{* * *} \\
(0.035)\end{array}$ & $\begin{array}{l}1.900^{* * *} \\
(0.727)\end{array}$ & \\
\hline Number of bank accounts & $\begin{array}{l}2.730^{* * *} \\
(0.750)\end{array}$ & $\begin{array}{l}0.051 \\
(0.033)\end{array}$ & $\begin{array}{l}2.824^{* * *} \\
(0.744)\end{array}$ & $\begin{array}{l}2.407^{* * *} \\
(0.784)\end{array}$ \\
\hline F-test on the excluded instruments & & & & 43.479 \\
\hline N. of observations & 4865 & 4865 & 4865 & 4865 \\
\hline
\end{tabular}

Notes: the table reports OLS, first-stage, intention-to-treat, and instrumental variable results of the model $w_{i p}=\widetilde{\alpha}+\widetilde{\beta} f l_{i p}+X_{i p} \widetilde{\gamma}+\lambda_{p}+\varepsilon_{i p}$ where $w_{i p}$ is financial assets owned by household $i$, living in province $p$, in year 2010; $f l_{i p}$ is financial literacy of the household head, $X_{i p}$ is a vector of household controls (as in the baseline specification of Table 3 plus the additional controls specified in each panel), and $\lambda_{p}$ is a province fixed effect. Financial literacy is instrumented with a dummy taking the value 1 if the household's main bank belongs to the PattiChiari Consortium and 0 otherwise.

Heteroskedasticity-robust standard errors clustered at the province level in parentheses.

${ }^{*} p<0.1,{ }^{* *} p<0.05,{ }^{* * *} p<0.01$. 
the rest of the sample ${ }^{32}$ We estimate the baseline regressions on the subsample of "investor households", with and without controlling for sources of financial information. Particularly, we control for an indicator that takes value 1 if the respondent relies only on that specific source of financial information and 0 otherwise (descriptive statistics of these variables are shown in Table 1). Results are reported in Table 7. Conditioning on sources of information does not alter the effect of the variables of interest. Moreover, the coefficients associated to sources of financial information are not statistically significant. These results support the absence of a significant direct effect of sources of financial information on wealth, other than through financial literacy. The reduced form (firststage and intention-to-treat) and instrumental variable estimates are shown not to be confounded by the direct effect of sources of financial information. It is worth noting that, when we restrict our analysis on the sample of "investor households", both the intention-to-treat and the effect of financial literacy on financial assets become larger in magnitude, although less precisely estimated with respect to the entire sample. This is informative of the potential heterogeneity of the effects in the population.

\subsection{Evidence on the Internal Validity of the Identification Strategy}

We exploit the panel dimension of the SHIW to perform an over-identificatoin test. We focus on households sampled for at least two consecutive waves over the period 2006-2010 (i.e. either in 2006 and 2008 or in 2008 and in 2010; 3196 observations) and we group them in four categories: households who remained clients of PattiChiari over the two waves (76.5\%), households who remained clients of a non-PattiChiari bank (13.2\%), and two groups of "switchers", i.e. those who moved from a PattiChiari to a non-PattiChiari bank (6.9\%), and vice-versa (3.4\%). These four groups identify three instrumental variables (plus a baseline group). All these variables can be used to predict financial literacy in 2010. Results are summarized in the first panel of Table 8 . The lower panel of Table 8 replicates the exercise focusing on bank-switchers over the 2006-2010 period (two waves). Despite the sample size is sensibly reduced, the main results of Table 3 are confirmed: one standard deviation rise in financial literacy causes an increase in financial assets by 12.7 and 9.6 thousand euros in, respectively, the upper and lower panels. Looking at the over-identification

\footnotetext{
${ }^{32}$ Average financial wealth of "investor households" is 38.22 thousand euros, compared to 19.38 thousand euros for the entire sample. The average number of correct answers on the questions measuring financial literacy is 2.2 among "investor households", 1.9 in the broad sample.
} 
Table 7: Effect of Financial Literacy on Financial Assets - Sample of "Investor Households", i.e. of households who invested some savings in financial markets (bonds, equities, investment funds, etc.)

\begin{tabular}{|c|c|c|c|c|c|c|}
\hline & OLS & FS & ITT & IV & $\mathrm{N}$ & F-test \\
\hline \multicolumn{7}{|c|}{ Panel A: "Investor Households", Baseline Specification as in Table 3} \\
\hline \multirow[t]{2}{*}{ Financial literacy } & $2.473^{* *}$ & & & $38.036^{*}$ & 1492 & 4.710 \\
\hline & $(1.022)$ & & & $(19.587)$ & & \\
\hline \multirow[t]{2}{*}{ Client of PattiChiari } & & $0.134^{* *}$ & $5.082^{* * *}$ & & & \\
\hline & & $(0.062)$ & $(1.306)$ & & & \\
\hline \multicolumn{7}{|c|}{ Panel B: "Investor Households", Controlling for Sources of Financial Information } \\
\hline \multirow[t]{2}{*}{ Financial literacy } & $2.314^{*}$ & & & $39.034^{*}$ & 1492 & 3.992 \\
\hline & $(1.022)$ & & & $(21.977)$ & & \\
\hline \multirow[t]{2}{*}{ Client of PattiChiari } & & $0.121^{* *}$ & $4.717^{* * *}$ & & & \\
\hline & & $(0.060)$ & $(1.279)$ & & & \\
\hline \multicolumn{7}{|l|}{ Source of Information } \\
\hline \multirow[t]{2}{*}{ Only Intermediaries and Experts } & -0.430 & 0.069 & -0.374 & -3.052 & & \\
\hline & $(2.256)$ & $(0.118)$ & $(2.119)$ & $(5.463)$ & & \\
\hline \multirow[t]{2}{*}{ Only Press and Websites } & -1.183 & 0.208 & -0.364 & -8.493 & & \\
\hline & $(5.231)$ & $(0.136)$ & $(5.278)$ & $(7.867)$ & & \\
\hline \multirow[t]{2}{*}{ Only Friends and Other } & -4.245 & -0.077 & -4.161 & -1.172 & & \\
\hline & $(2.771)$ & $(0.120)$ & $(2.675)$ & $(5.044)$ & & \\
\hline $\begin{array}{l}\text { Notes: "Investor households": household that inves } \\
\text { of the table reports OLS, first-stage, intention-to-t } \\
\text { where } w_{i p} \text { is financial assets owned by household } i \\
\text { a vector of household controls as in the baseline sp } \\
\text { with a dummy taking the value } 1 \text { if the household's } \\
\text { standard errors clustered at the province level in p. } \\
{ }^{*} p<0.1,{ }^{* *} p<0.05,{ }^{* * *} p<0.01 .\end{array}$ & $\begin{array}{l}\text { ed some savin } \\
\text { reat, and instr } \\
\text { living in prov } \\
\text { ecification of } \\
\text { main bank bel } \\
\text { rentheses. }\end{array}$ & $\begin{array}{l}\text { S in financial } \\
\text { imental variab } \\
\text { ince } p \text {, in year } \\
\text { able } 3 \text { and } \lambda_{p} \\
\text { ngs to the Patt }\end{array}$ & $\begin{array}{l}\text { arkets (bonds, } \\
\text { e results of the } \\
2010 ; f l_{i p} \text { is fir } \\
\text { is a province fi } \\
\text { Chiari Consorti }\end{array}$ & $\begin{array}{l}\text { quities, invest } \\
\text { nodel } w_{i p}=0 \\
\text { ancial literacy } \\
\text { ed effect. Fina } \\
\mathrm{n} \text { and } 0 \text { otherw }\end{array}$ & $\begin{array}{l}\text { ent funds, e } \\
+\widetilde{\beta} f l_{i p}+X \\
\text { the househ } \\
\text { cial literacy } \\
\text { e. Heterosk }\end{array}$ & $\begin{array}{l}\text { c.). Each } \\
i p \tilde{\gamma}+\lambda_{p} \\
\text { ld head, } \\
\text { is instrun } \\
\text { dasticity- }\end{array}$ \\
\hline
\end{tabular}


test, the Hansen J statistic does not reject the null hypothesis of exogeneity of the instruments at all conventional levels of significance: the p-value associated to the test is 0.43 in the top panel of Table 8 and 0.75 in the bottom panel.

\subsection{Sensitivity Analysis: Sample Selection and Functional Form}

Our estimation sample excludes the upper and lower $5 \%$ tails of the financial assets distribution. However, in the bottom part of the distribution there are tied values: about $11 \%$ of the households do not have any financial asset. One may question whether our results are driven by sample selection, i.e. by the fact that we focus on households with positive financial assets. Panel A in Table 9 presents estimates of our baseline model on a sample that includes households with zero assets. In Panel B, we use a Tobit model to distinguish the effect of financial literacy on the probability of having any financial asset from its effect on the amount of assets owned. In both cases, we contrast the results of the instrumental variable approach with those obtained when we consider financial literacy as an exogenous variable. Results broadly confirm the findings illustrated in Section 6. When endogeneity is not addressed, the effect of financial literacy on financial assets is underestimated. The magnitude of the instrumental variable estimates on average assets is fairly similar to the one discussed in Section 6. Some interesting new findings emerge: instrumental variable estimates from the Tobit model suggest that financial literacy affects both the decision to hold financial assets as well as their amount, so that the marginal effect of one additional correct answer to the financial literacy questions is lower for those who hold financial assets $(+7$ thousand euros) than for the average individual (+ nearly 10 thousand euros) ${ }^{33}$

\subsection{Extensions}

Financial literacy can affect wealth through many different channels ${ }^{34}$ With the data at our hand, we can analyse two potentially relevant mechanisms that may drive the positive effect mea-

\footnotetext{
${ }^{33}$ Notice, however, that this model has two drawbacks: first, it imposes restrictions on the effect of financial literacy over the intensive and the extensive margins; second, it is well suited for continuous endogenous variables. For these reasons, we choose as baseline the results delivered by linear models.

${ }^{34}$ We refer to Jappelli and Padula (2013b) (note 5) and Lusardi et al. (2011) for a discussion of the links between financial literacy and financial wealth. Relevant channels relate to expectations (literate individuals may be more accurate and/or less biased), preferences (financial literacy may ease the understanding of risk and reducing 'direct risk aversion'), perceptions (financial literacy may reduce underestimation of compounding effects), diversification, and the cost charged on loans or mutual funds.
} 
Table 8: Association and Causal Effect of Financial Literacy on Financial Assets with Instruments that Use Information on "Bank-Switchers" Between Two years (i.e. Between Survey Waves) or Between Four Years (Between Two Survey Waves).

HHs observed in 2006-2008 or in 2008-2010

Descriptive statistics -Avg (se)- on this sample

Financial Assets: 22.9 (29.9); Financial Literacy : 1.46 (0.68)

OLS FS ITT IV

Financial literacy*

$2.009^{* *}$

$18.673^{* *}$

Switchs to Client of PattiChiari

(1.008)

Stays Client of Non-PattiChiari

Switchs to Client of Non-PattiChiari

$\begin{array}{ccc} & -0.108 & -0.989 \\ & (0.067) & (2.317) \\ & -0.133^{* * *} & -3.660^{* *} \\ & (0.048) & (1.448) \\ & -0.183^{* * *} & -1.980 \\ & (0.048) & (1.884) \\ 3196 & 3196 & 3196\end{array}$

3196

N. of observations

3196

3196

0.4269

Hansen J p-value

HHs observed in 2006 and 2010

Descriptive statistics -Avg (se)- on this sample

Financial Assets : 21.9 (23.8); Financial Literacy: 1.43 (0.68)

OLS FS ITT IV

Financial literacy* $\quad 1.245$

$14.081^{*}$

$(1.091)$

Switchs to Client of PattiChiari

$\begin{array}{cc} & \\ -0.009 & 0.405 \\ (0.088) & (2.991) \\ -0.197^{* * *} & -3.072^{* *} \\ (0.064) & (1.299) \\ -0.087 & 0.638 \\ (0.071) & (2.759) \\ 1560 & 1560\end{array}$

Stays Client of Non-PattiChiari

Switchs to Client of Non-PattiChiari

1560

1560

1560

1560

Hansen J p-value

0.7535

Notes: * We consider the two questions common across waves. The baseline analysis on year 2010 considers three questions. See appendix Appendix A for more details. The table reports OLS, first-stage, intention-to-treat, and instrumental variable results of the model $w_{i p}=$ $\widetilde{\alpha}+\beta f l_{i p}+X_{i p} \widetilde{\gamma}+\lambda_{p}+\varepsilon_{i p}$ where $w_{i p}$ is financial assets owned by household $i$, living in province $p$, in year $2010 ; f l_{i p}$ is financial literacy of the household head, $X_{i p}$ is a vector of household controls (as in the baseline specification of Table 3 , and $\lambda_{p}$ is a province fixed effect. Financial literacy is instrumented with three dummies identifying whether household switched from being a PattiChiari to a non-PattiChiari bank (or vice-versa) or remained client of non-PattiChiari banks between 2008 and 2010 (in the top panel) or between 2006 and 2010 (in the bottom one). Heteroskedasticity-robust standard errors clustered at the province level in parentheses.

$p<0.1, \quad p<0.05, * * 0.01$. 
Table 9: Robustness: Sample Selection and Functional Form

\begin{tabular}{lcccc}
\hline \hline \multicolumn{5}{c}{ Panel A } \\
\multicolumn{5}{c}{ Baseline model including households with no financial asset } \\
& OLS & FS & ITT & IV \\
Financial literacy & $2.106^{* * *}$ & & & $6.342^{* *}$ \\
& $(0.539)$ & & & $(2.664)$ \\
Client of PattiChiari & & $0.238^{* * *}$ & $1.509^{* *}$ & \\
& & $(0.034)$ & $(0.629)$ & \\
F-test of excluded instruments & & & 49.278 \\
N. of observations & & & \\
\hline \hline
\end{tabular}

\section{Panel B}

Tobit regression model results

Coefficient of

Financial Literacy

$2.593^{* * *}$

$(0.621)$

\begin{tabular}{ccc}
\multicolumn{3}{c}{ Average Partial Effects on } \\
$E[Y]$ & $E[Y \mid Y>0]$ & $\operatorname{Prob}[Y>0]$ \\
$2.005^{* * *}$ & $1.442^{* * *}$ & $0.038^{* * *}$ \\
$(0.475)$ & $(0.341)$ & $(0.009)$
\end{tabular}

Instrumental variable Tobit regression model results
Coefficient of

Financial Literacy

$13.094^{* * *}$

$(3.425)$

$\mathrm{N}$
Average Partial Effects on

$\begin{array}{ccc}E[Y] & E[Y \mid Y>0] & \operatorname{Prob}[Y>0] \\ 9.881^{* * *} & 7.056^{* * *} & 0.183^{* * *} \\ (2.583) & (1.845) & (0.048) \\ & & \\ & 5451 & \end{array}$

Notes: Models include the same vector of household controls as in the baseline specification of Table 3 and province fixed effects. Financial Notes: Models include the same vector of household controls as in the baseline specification of Table 3 and province fixed effects. Financial
literacy is instrumented with a dummy that takes the value 1 if the household's main bank belongs to the PattiChiari Consortium and 0 otherwise. Heteroskedasticity-robust standard errors clustered at the province level in parentheses. ${ }^{*} p<0.1,{ }^{* *} p<0.05,{ }^{* * *} p<0.01$. 
sured in the aggregate. First, we investigate whether literate respondents are more prone to plan for retirement (Lusardi and Mitchell, 2008, van Rooij et al., 2011a). Retirement planning may enhance saving and, in turn, may be associated with a higher stocks of financial assets. Second, we asses whether financial literacy fosters participation to the stock market van Rooij et al. 2011b c Christelis et al. 2010). We expect financial literate respondents to hold a better-diversified portfolio and, in turn, to be more likely to hold risky assets.

To analyze the role of retirement planning, we use answers to the following question (not asked to retirees): "Have you ever thought about how to arrange for your household's support when you retire?". We also consider a binary indicator of household participation to the stock market, either directly or through a mutual fund. Table 10 reports the OLS, FS, ITT and IV estimates for these outcomes. While the correlation is positive, we fail to detect a significant causal effect of financial literacy on the likelihood of planning for retirement (see IV estimates). This finding may reflect the fact that Italy is characterized by a generous pension system, compared to other countries, and relatively high saving rates: undersaving to meet retirement target in Italy might thus be a less relevant issue with respect to other countries.

Conversely, we find a positive and significant effect of financial literacy on stock market participation. Portfolio diversification may enhance returns of households' savings and, thus, this channel may contribute to explain the positive effect of financial literacy on financial assets we document in this paper. Compared to other countries, Italy is indeed characterized by relatively low participation to the stock market.

Lastly, we look at various dimensions of heterogeneity, and estimate our baseline model on different sub-samples: we find that the impact of financial literacy is slightly larger for households living in large cities, in northern or central Italy, and where the household head is male, even though the first stage effect is larger for women. Results are not reported here for brevity but are available from the authors upon request.

\section{Concluding remarks}

The interests by scholars and policy-makers, in Europe and in the U.S., on the determinants of financial literacy and on the link between financial literacy and wealth has been constantly increasing in the last years. Institutions, such as the OECD, the U.S. Treasury Department and 


\begin{tabular}{|c|c|c|c|c|}
\hline & OLS & FS & ITT & IV \\
\hline \multicolumn{5}{|c|}{ Panel A: Planning for retirement* } \\
\hline \multirow[t]{2}{*}{ Financial literacy } & $0.039^{* * *}$ & & & 0.197 \\
\hline & $(0.014)$ & & & $(0.122)$ \\
\hline \multirow[t]{2}{*}{ Client of PattiChiari } & & $0.213^{* * *}$ & 0.042 & \\
\hline & & $(0.048)$ & $(0.026)$ & \\
\hline N. of observations & 2653 & 2653 & 2653 & 2653 \\
\hline Ftest & & & & 19.967 \\
\hline \multicolumn{5}{|c|}{ Panel B: Stock market participation } \\
\hline \multirow[t]{2}{*}{ Financial literacy } & $0.019^{* * *}$ & & & $0.134^{* * *}$ \\
\hline & $(0.006)$ & & & $(0.047)$ \\
\hline \multirow[t]{2}{*}{ Client of PattiChiari } & & $0.235^{* * *}$ & $0.031^{* * *}$ & \\
\hline & & $(0.035)$ & $(0.010)$ & \\
\hline N. of observations & 4865 & 4865 & 4865 & 4865 \\
\hline Ftest & & & & 43.849 \\
\hline
\end{tabular}

Notes: the table reports OLS, first-stage, intention-to-treat, and instrumental variable results of the model $D V_{i p}=\widetilde{\alpha}+\widetilde{\beta} f l_{i p}+X_{i p} \widetilde{\gamma}+\lambda_{p}+$ $\varepsilon_{i p}$ where $D V_{i p}$ is a dependent variable measured for household $i$, living in province $p$, in year $2010 ; f l_{i p}$ is financial literacy of the household head, $X_{i p}$ is a vector of household controls (as in the baseline specification of Table 3 , and $\lambda_{p}$ is a province fixed effect. Financial literacy is instrumented with a dummy taking the value 1 if the household's main bank belongs to the PattiChiari Consortium and 0 otherwise. In the top panel the dependent variable is a dummy equal to 1 if the household head reports to have planned for retirement, in the bottom panel is a dummy equal to 1 if the household owns stocks or mutual funds.

* Respondents who are asked the question about retirement planning have average (standard deviation) financial literacy of 2.085 (0.900). Heteroskedasticity-robust standard errors clustered at the province level in parentheses.

${ }^{*} p<0.1,{ }^{* *} p<0.05,{ }^{* * *} p<0.01$ 
the Bank of Italy, have expressed the need for improved financial knowledge, emphasizing the role of formal financial education in schools or at the workplace.

This research contributes to the investigation of these issues introducing a new and possibly complementary policy instrument. We start recognizing the role of banks information policies in reducing the cost of investing in financial literacy and we posit a novel question: do banks information policies have the potential to increase financial literacy and, in turn, household financial wealth? To answer this question, we identify a group of Italian banks, the PattiChiari Consortium, that implements active policies aimed at increasing transparency.

We exploit a unique representative sample of Italian households that collects information on which banks the household is client of, household financial literacy, and detailed information on financial assets. We find that being client of a PattiChiari bank translates into a $12 \%$ increase in financial literacy. This complements previous findings by Mastrobuoni (2011), who shows that availability of information on social security benefits in the U.S. has significant impact on workers' knowledge. We add to previous literature by showing that adults financial literacy (and financial assets) can be fostered through interventions that are alternative to financial education programs. We then use the exogenous variation in financial literacy induced by banks information policies to assess the effect of financial literacy on financial assets. In line with previous literature, our findings suggest that this relationship is largely underestimated by simple OLS correlation. All results are shown to be robust to several alternative explanations and robustness checks.

Assessing whether banks' information policies are more effective to foster financial literacy with respect to other interventions is still an open issue. The data at our hands do not allow to perform this policy-relevant comparative analysis: we leave this issue for further research. 


\section{Acknowledgements}

We acknowledge the financial support of MIUR- FIRB 2008 project RBFR089QQC-003-J31J10000060001. We thank E. Battistin, R. Bottazzi, T. Bucher-Koenen, M. Cervellati, M. Giofré, M. Hurd, T. Kuchler, P. Legrenzi, B. Luppi, M. Padula, G. Pasini, E. Rettore, E. Sette, M. Wakefield, Y. Winter and participants to the BoMoPaV Economics Meeting in Padua, the Netspar International Pension Workshop in Paris, the SAVE-PHF Conference in Munich, the CERP Annual Conference on Financial Literacy, Saving and Retirement in an Ageing Society, the European Association of Labour Economists (EALE) Annual conference in Bonn, Munich Center for the Economics of Aging (MEA) and seminars at the University of Bologna and at the Johannes Kepler University of Linz for useful comments on an earlier version of this work. We thank the Bank of Italy Banking and Financial Supervision Area (notably, P. Franchini and A. Scognamiglio) for kindly providing data on bank account costs. We are indebted with the PattiChiari Consortium (notably, V. Panna and L. Napoleoni) for the data provided and for intriguing discussions about their initiatives. Margherita Fort is affiliated with IZA (Institute for the Study of Labor, Bonn) and CESifo; she was affiliated with CHILD during the early stages of this project. M. Fort acknowledges support from CESIFO for hospitality. Serena Trucchi is affiliated with CeRP (Center for Research on Pensions and Welfare Policies). The views here expressed are those of the authors and do not necessarily reflect those of the Bank of Italy. The usual disclaimer applies. 


\section{Appendix A. Measuring Financial Literacy}

The three questions available in the 2010 wave for eliciting financial literacy are: i) understanding inflation "Imagine leaving 1,000 euros in a current account that pays 1\% interest and has no charges. Imagine also that inflation is running at 2\%. Do you think that if you withdraw the money in a year's time you will be able to buy the same amount of goods as if you spent the 1,000 euros today? Yes/No, I will be able to buy less (correct answer)/No, I will be able to buy more/Do not know"; ii) understanding mortgages "Which of the following types of mortgage do you think will allow you from the very start to fix the maximum amount and number of installments to be paid before the debt is extinguished? Floating rate mortgage/Fixed rate mortgage (correct answer)/Floating rate mortgage with fixed installments/Do not know"; iii) portfolio diversifica-

tion" Which of the following investment strategies do you think entails the greatest risk of losing your capital? Investing in the shares of a single company (correct answer) / Investing in the shares of more than one company/Do not know/No answer".

Questions (i) and (iii) are similar to the ones devised for the US Health and Retirement Study (HRS) (Lusardi and Mitchell, 2011a) while knowledge of mortgage repayment mechanisms is not considered in the HRS. All these questions follow the principles of simplicity, relevance, brevity and capacity to differentiate identified by Lusardi and Mitchell (2011c). Questions (i) and (ii) are common to all three waves of SHIW used in this paper $(2006,2008,2010)$. In addition, in 2006 financial literacy questions were asked to approximately half of the sample, i.e. to household heads born in even years. 


\section{References}

Altman, M., 2012. Implications of Behavioural Economics For Financial Literacy and Public Policy. Journal of Socio-Economics 41, 677-690.

Angrist, J., 2004. Treatment Effect Heterogeneity in Theory and Practice. The Economic Journal 114, C52-C83, issue 494.

Angrist, J. D., Imbens, G. W., Rubin, D. B., 1996. Identification of Causal Effects Using Instrumental Variables. Journal of the American Statistical Association 91, 444-455.

Biagi, F., Giraldo, A., Rettore, E., 2009. Gli Effetti dell'Attrito sulla Stima della Disuguaglianza in Italia. In: Brandolini A., C. Saraceno, A. S. (Ed.), Dimensioni della Disuguaglianza in Italia: Povertà, Salute, Abitazione. Il Mulino.

Bucher-Koenen, T., Lusardi, A., 2011. Financial Literacy and Retirement Planning in Germany. Journal of Pension Economics and Finance 10 (4).

Calcagno, R., Monticone, C., 2014. Financial Literacy and the Demand for Financial Advice. Journal of Banking and Finance.

Carpena, F., Cole, S., Shapiro, J., Zia, B., 2011. Unpacking the Causal Chain of Financial Literacy. Policy Research Working Paper 5798, World Bank.

Christelis, D., Jappelli, T., Padula, M., 2010. Cognitive Abilities and Portfolio Choice. European Economic Review 54 (1).

Disney, R., Gathergood, J., 2011. Financial Literacy and Indebtedness: New Evidence for UK consumers. Discussion papers, University of Nottingham, Centre for Finance, Credit and Macroeconomics (CFCM).

Fornero, E., Monticone, C., 2011. Financial Literacy and Pension Plan Participation in Italy. Journal of Pension Economics and Finance 10 (4).

Garcia, M., 2013. Financial Education and Behavioral Finance: New Insights Into The Role of Information in Financial Decisions. Journal of Economic Surveys 27 (2), 297-315. 
Georgarakos, D., Inderst, R., 2011. Financial Advice and Stock Market Participation. Working Paper 1296, European Central Bank.

Hastings, J. S., Madrian, B. C., Skimmyhorn, W. L., 2013. Financial Literacy, Financial Education, and Economic Outcomes. Annual Review of Economics, Annual Reviews 5 (1), 347-373.

Jappelli, T., 2010. Economic Literacy: An International Comparison. The Economic Journal $120(548)$.

Jappelli, T., Padula, M., 2013a. Consumption Growth, the Interest Rate, and Financial Literacy. CSEF Working Papers 329, Centre for Studies in Economics and Finance (CSEF), University of Naples, Italy.

Jappelli, T., Padula, M., 2013b. Investment in Financial Literacy and Saving Decisions. Journal of Banking and Finance 27 (08), 2779-2792.

Jappelli, T., Pischke, J., Souleles, N., 1998. Testing for Liquidity Constraints in Euler Equations With Complementary Data Sources. Review of Economics and Statistics 80 (2).

Klapper, L., Lusardi, A., Panos, G. A., 2013. Financial Literacy and its Consequences: Evidence from Russia During the Financial Crisis. Journal of Banking and Finance 37.

Klapper, L., Panos, G. A., 2011. Financial Literacy and Retirement Planning: the Russian case. Journal of Pension Economics and Finance 10.

Lusardi, A., Michaud, P.-C., Mitchell, O. S., Sep. 2011. Optimal Financial Literacy and Saving for Retirement. Working papers, RAND Corporation Publications Department.

Lusardi, A., Mitchell, O. S., 2007. Financial Literacy and Retirement Preparedness: Evidence and Implications for Financial Education. Business Economics 42 (1).

Lusardi, A., Mitchell, O. S., 2008. Planning and Financial Literacy: How Do Women Fare? American Economic Review 98 (2).

Lusardi, A., Mitchell, O. S., 2009. How Ordinary Consumers Make Complex Economic Decisions: Financial Literacy and Retirement Readiness. NBER Working Papers 15350, National Bureau of Economic Research, Inc. 
Lusardi, A., Mitchell, O. S., 2011a. Financial Literacy and Planning: Implications for Retirement Wellbeing. In: Lusardi, A., Mitchell, O. S. (Eds.), Financial Literacy: Implications for Retirement Security and the Financial Marketplace. Oxford: Oxford University Press.

Lusardi, A., Mitchell, O. S., 2011b. Financial Literacy and Retirement Planning in the United States. Journal of Pension Economics and Finance 10 (04).

Lusardi, A., Mitchell, O. S., 2011c. Financial Literacy Around the World: An Overview. Journal of Pension Economics and Finance 10.

Lusardi, A., Mitchell, O. S., 2014. The Economic Importance of Financial Literacy: Theory and Evidence. Journal of Economic Literature 52 (1).

Manski, C., 1993. Identification of Endogenous Social Effects: the Reflection Problem. The Review of Economic Studies 60 (3), 531-542.

Mastrobuoni, G., 2011. The Role of Information for Retirement Behavior: Evidence Based on the Stepwise Introdution of the Social Security Statement. Journal of Public Economics 95, 913-925.

OECD, September 2013a. Evaluating Financial Education Programmes: Survey, Evidence, Policy Instruments and Guidance.

OECD, June 2013b. Improving Financial Education Effectiveness Through Behavioural Economics.

Staiger, D., Stock, J., 1997. Instrumental Variables Regression With Weak Instruments. Econometrica $65,557-586$.

van Rooij, M., Lusardi, A., Alessie, R., 2011a. Financial Literacy and Retirement Preparation in the Netherlands. Journal of Pension Economics and Finance 10.

van Rooij, M., Lusardi, A., Alessie, R., 2011b. Financial Literacy and Stock Market Participation. Journal of Financial Economics 101 (2).

van Rooij, M., Lusardi, A., Alessie, R., 2011c. Financial Literacy, Retirement Planning, and Household Wealth. Economic Journal.

Willis, L. E., 2011. The Financial Education Fallancy. American Economic Review: Papers and Proceedings, 429-434. 